\title{
In vitro expression of NGN3 identifies RAB3B as the predominant Ras-associated GTP-binding protein 3 family member in human islets
}

\author{
Karen Piper Hanley*, Tom Hearn ${ }^{1, *}$, Andrew Berry, Melanie J Carvell ${ }^{2}$, Ann-Marie Patch ${ }^{3}$, \\ Louise J Williams ${ }^{1}$, Sarah A Sugden, David I Wilson ${ }^{1}$, Sian Ellard ${ }^{3}$ and Neil A Hanley \\ Endocrinology and Diabetes Group, Manchester Academic Health Science Centre, University of Manchester, A V Hill Building, Oxford Road, \\ Manchester M13 9PT, UK \\ ${ }^{1}$ Human Genetics Division, University of Southampton, Southampton, SO16 6YD UK \\ ${ }^{2}$ Beta-Cell Development and Function Group, King's College London, Guy's Campus, London SE1 1UL, UK \\ ${ }^{3}$ Peninsula Medical School, Institute of Biomedical and Clinical Science, Barrack Road, Exeter EX2 5DW, UK \\ (Correspondence should be addressed to N A Hanley; Email: neil.hanley@manchester.ac.uk) \\ *(K Piper Hanley and T Hearn contributed equally to this work)
}

\begin{abstract}
Neurogenin 3 (NGN3) commits pancreatic progenitors to an islet cell fate. We have induced NGN3 expression and identified upregulation of the gene encoding the Ras-associated small molecular mass GTP-binding protein, RAB3B. RAB3B localised to the cytoplasm of human $\beta$-cells, both during the foetal period and post natally. Genes encoding alternative RAB3 proteins and RAB27A were unaltered by NGN3 expression and in human adult islets
\end{abstract}

their transcripts were many fold less prevalent than those of $R A B 3 B$. The regulation of insulin exocytosis in rodent $\beta$-cells and responsiveness to incretins are reliant on $\mathrm{Rab}$ family members, notably Rab3a and Rab27a, but not Rab3b. Our results support an important inter-species difference in regulating insulin exocytosis where $\mathrm{RAB} 3 \mathrm{~B}$ is the most expressed isoform in human islets.

Journal of Endocrinology (2010) 207, 151-161

\section{Introduction}

Understanding normal $\beta$-cell development and function underpins various efforts aimed to restore $\beta$-cells in patients with type 1 and type 2 diabetes. During the foetal development, the pancreas contains epithelial progenitor cells, which give rise to the adult cell lineages, including $\beta$-cells (Murtaugh 2007). Experiments manipulating genes in mice have discovered a multitude of transcription factors that regulate this transition (Wilson et al. 2003). Within a subset of progenitors, positive for the transcription factors Sry box 9 (Sox9) and pancreas-duodenal homeobox 1 (Pdx1), the basic helix-loop-helix (bHLH) transcription factor Neurogenin-3 (Ngn3, also known as Neurog3) becomes transiently expressed to commit cells to an endocrine fate (Schwitzgebel et al. 2000, Lynn et al. 2007, Seymour et al. 2007). Without Ngn3, islet differentiation fails (Gradwohl et al. 2000). The transcription factor has also been shown necessary for $\beta$-cell regeneration from adult precursors (Xu et al. 2008). Strategies, such as expression microarray following retroviral ectopic Ngn3 expression, have identified direct genetic targets of Ngn 3 encoding transcription factors, such as NeuroD1, paired homeobox factor 4 (Pax4), Nirenberg and Kim (NK) homeobox family member Nkx2.2 and insulinoma-associated 1 , all of which when inactivated in mice impair $\beta$-cell differentiation (Sosa-Pineda et al. 1997, Sussel et al. 1998, Huang et al. 2000, Heremans et al. 2002, Gasa et al. 2004, Smith et al. 2004, Mellitzer et al. 2006). Pdx1 is also increased following Ngn3 expression (Gasa et al. 2004). Several of these transcription factors downstream of Ngn3 are then required for mature $\beta$-cell function. For instance, $\mathrm{Pdx} 1$ regulates GLUT2, glucokinase and insulin amyloid polypeptide (IAPP) expression (McKinnon \& Docherty 2001) and, in association with NeuroD1, it transactivates the insulin gene (Babu et al. 2008).

Many aspects of the $\beta$-cell phenotype are conserved across species. Nevertheless, there are subtle differences in mature $\beta$-cell function between mice and humans: the relative roles of glucose transport and phosphorylation as a part of glucose sensing (Schuit 1997); responsiveness to glucokinase activators (Johnson et al. 2007); glucose-induced desensitisation (Zawalich et al. 1998); responses to galanin (McDonald et al. 1994) and melatonin (Ramracheya et al. 2008); the roles of Pax4 (Brun et al. 2008) and p57Kip2 (Potikha et al. 2005) in $\beta$-cell proliferation; and, central to $\beta$-cell function, regulation of the insulin promoter (Hay \& Docherty 2006). This makes direct study of human pancreas development and $\beta$-cells worthwhile. Studying foetuses from first trimester termination of pregnancy has provided a framework for understanding early human pancreas development with $\beta$-cells 
increasing rapidly after 8 weeks post conception (wpc), first as cell clusters and then within islets, where they express other markers of maturity such as prohormone convertase $1 / 3$, IAPP, chromogranin A and some components of the glucosesensing apparatus (Piper et al. 2004, Richardson et al. 2007). Similar studies first identified SOX9 as important for pancreatic development and $\beta$-cell differentiation; the pancreata of patients with campomelic dysplasia being hypoplastic and composed of poorly formed islets (Piper et al. 2002). Human pancreatic progenitor cells expressing PDX1 (Piper et al. 2004) and NGN3 transcripts have been identified at $8 \mathrm{wpc}$ (Castaing et al. 2005).

To further address the potential inter-species differences downstream of endocrine commitment, we induced human NGN3 expression in a cell line with similarities to human foetal pancreatic progenitors, leading to increased expression of the Ras-associated small molecular mass GTP-binding protein, RAB3B. RAB3 proteins regulate intracellular trafficking and exocytosis in a range of cell types (Gonzalez \& Scheller 1999) with RAB3B recently implicated in protecting and enhancing the function of dopaminergic nerve terminals (Chung et al. 2009). Inactivation of either $R a b 3 a$ or Rab27, but not Rab3b, in mice causes glucose intolerance (Yaekura et al. 2003, Aizawa \& Komatsu 2005, Kasai et al. 2005). In this study, we have identified RAB3B, rather than RAB27A or other RAB3 isoforms, as the predominant isoform in human islets implying an interspecies difference and providing a new candidate for mutation or abnormal function as a cause of diabetes and as a potential therapeutic target for enhancing insulin secretion in humans.

\section{Materials and Methods}

\section{Human tissue collection}

The collection of human foetal material under guidelines issued by the Polkinghorne committee has been described previously (Piper et al. 2004, Ostrer et al. 2006). Ethical approval was granted by the Southampton and South West Hampshire Local Regional Ethics committee. In these experiments, material from at least two foetuses per stage was examined. Human islets were obtained with appropriate ethical approval from the King's College Hospital Islet Transplantation Unit (King's College Hospital, London, UK). Pancreata were removed from non-diabetic cadaver organ donors and islets were isolated under aseptic conditions as described previously (Huang et al. 2004).

\section{Immunohistochemistry and immunoblotting}

Tissue preparation, immunoblotting, immunohistochemistry and immunofluorescence were performed as described previously (Piper et al. 2004, Piper Hanley et al. 2008). Antibodies are listed in Supplementary Table 1, see section on supplementary data given at the end of this article with dilutions, catalogue numbers and sources. Exceptions to dilutions for immunoblotting were 1:1000 for NGN3 and RAB3B. For biotinylated secondary antibodies, streptavidin (SA)-HRP (1:200, Vector Laboratories Ltd, Peterborough, UK), SA-FITC (1:150, Sigma-Aldrich Ltd), or SA-Texas Red (1:200; Vector Laboratories Ltd) conjugates were used according to the manufacturers' instructions. For bright-field immunohistochemistry, the colour reaction was developed following SA-HRP with diaminobenzidine (Merck) containing $0 \cdot 1 \%$ hydrogen peroxidase (Sigma-Aldrich Ltd). Negative controls were omission of primary or secondary antibody.
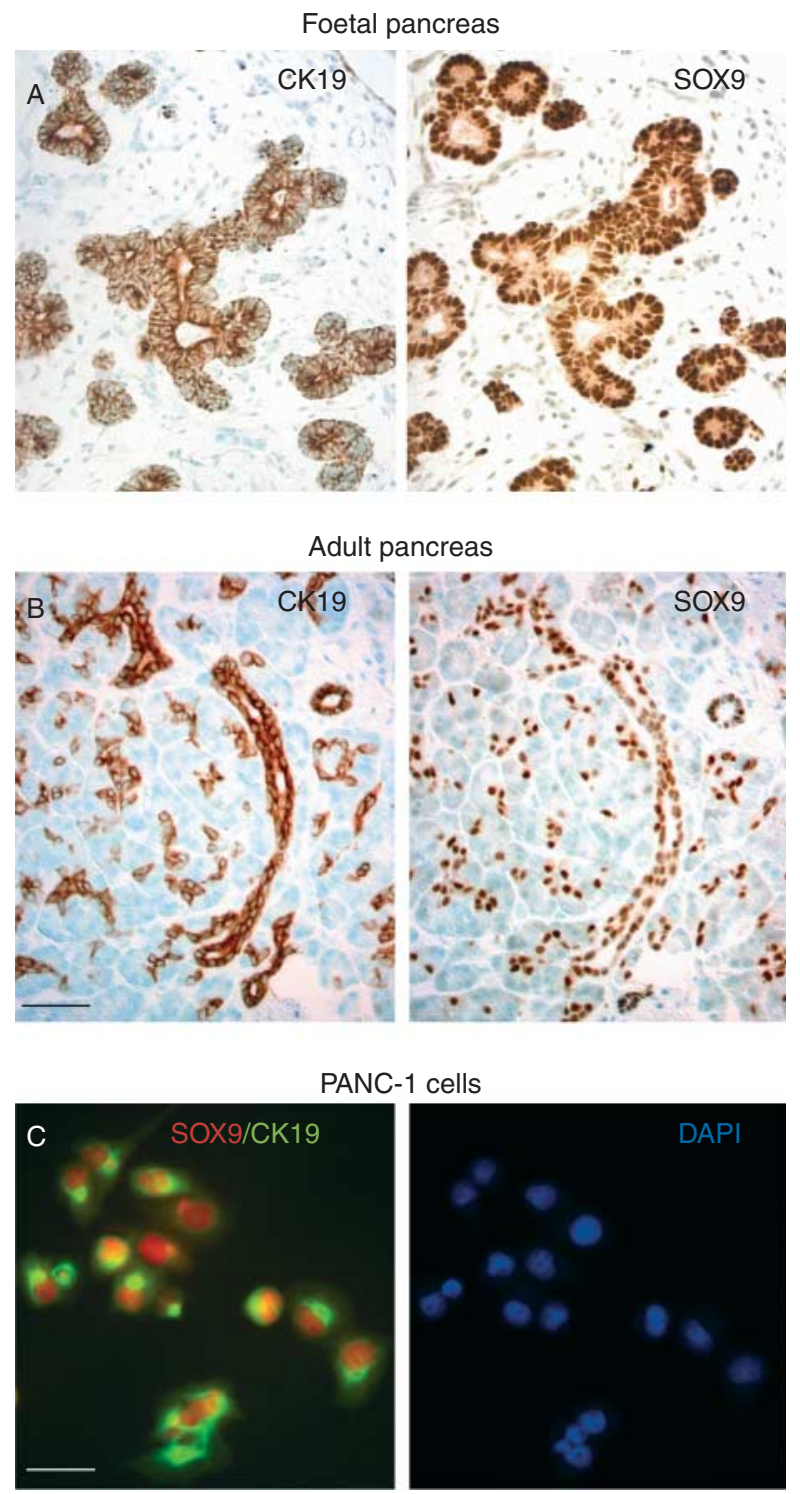

Figure 1 PANC-1 cells express CK19 and SOX9. (A) Consecutive $5 \mu \mathrm{m}$ sections of the human foetal pancreas at $8 \mathrm{wpc}$ stained for CK19 and SOX9. (B) Consecutive $5 \mu \mathrm{m}$ sections of the human adult pancreas stained for CK19 and SOX9. (C) Dual immunofluorescence of PANC-1 cells for SOX9 (red) and CK19 (green) counterstained with DAPI (blue) of the same image is shown to the right. Size bars represent $250 \mu \mathrm{m}(\mathrm{A}$ and $\mathrm{B})$ and $50 \mu \mathrm{m}(\mathrm{C})$. 
Cloning of the PANC-1 cell line with inducible NGN3 expression

The human PANC-1 cell line (cat. no. 87092802) was purchased from the European Cell and Animal Culture Collection (ECACC, Salisbury, UK) and cultured in DMEM containing 10\% foetal bovine serum (FBS) and prokaryotic antibiotics. All vectors were from Clontech Laboratories Inc. The human NGN3 coding sequence was amplified by PCR using primers containing HindIII and XbaI restriction sites (forward, 5'-CCCAAGCTTGACTCAAACTTACCCTTCCCTCTG-3'; reverse, 5'-GCTCTAGAGCTCCGGCCGGGTAGTGCT- ${ }^{\prime}$ ) and cloned using these restriction sites into the pTRE2 vector to create pTRE2-NGN3. PANC-1 cells were transfected sequentially with pTet-On and pTRE2-NGN3 plus pTK-Hyg using Transfast (Promega Ltd). Stable PANC-1 clones demonstrating inducible NGN3 expression (PANC-1 $1_{\text {iNGN3 }}$ ) were isolated in DMEM containing tetracycline-free FBS by selection with G418 and hygromycin according to the manufacturer's instructions (Clontech Laboratories). To assess the expression of functional

A Doxycycline $(\mu \mathrm{g} / \mathrm{ml})$

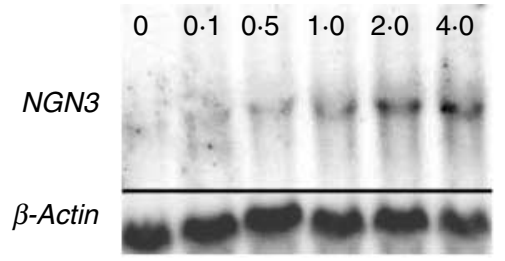

B

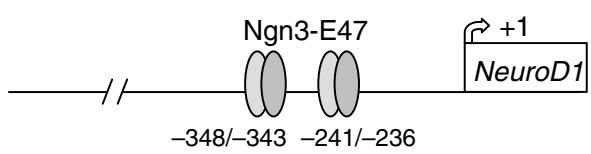

C

\begin{tabular}{lcc}
\hline PANC- $1_{\text {iNGN }}$ clone & Fold induction & S.E.M. \\
\hline Clone 9 & 2.24 & \pm 0.48 \\
Clone 15 & 1.71 & \pm 0.39 \\
Clone 40 & 1.45 & \pm 0.48 \\
Clone 51 & 1.97 & \pm 0.27 \\
\hline
\end{tabular}

NGN3 protein, the proximal $1613 \mathrm{bp}$ of $5^{\prime}$ flanking region from the mouse NeuroD1 gene was amplified to create a luciferase construct, p-1613NeuroD1-Luc. This construct contains two E-box motifs regulated by Ngn3 (Huang et al. 2000). Luciferase assays (Promega Corp.), as described previously (Hanley et al. 2001), were conducted $48 \mathrm{~h}$ after the addition of doxycycline (Dox) to screen PANC- $1_{\text {iNGN3 }}$ clones for induction of functional NGN3.

Isolation of RNA, northern blotting, reverse transcription and real-time PCR

Total RNA was isolated from PANC- $1_{\text {iNGN3 }}$ cells, human foetal pancreas and adult islets using Tri reagent (SigmaAldrich Ltd) for subsequent gel electrophoresis and reverse transcription (RT) using Superscript III (Invitrogen Ltd). RNA gel electrophoresis was carried out under denaturing conditions using $5 \mu \mathrm{g}$ of total RNA per lane followed by washing and transfer overnight to Hybond $\mathrm{N}+$ membrane (Amersham Pharmacia Biotech Ltd). The membrane was

\begin{tabular}{lcc}
\hline Gene & Fold induction & S.E.M. \\
\hline NGN3 & 2.98 & \pm 0.28 \\
RAB3B & 2.50 & \pm 0.08
\end{tabular}

E Doxycycline $(\mu \mathrm{g} / \mathrm{ml})$

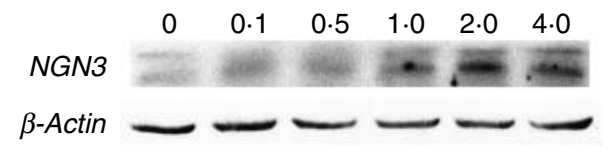

$\mathrm{F}$

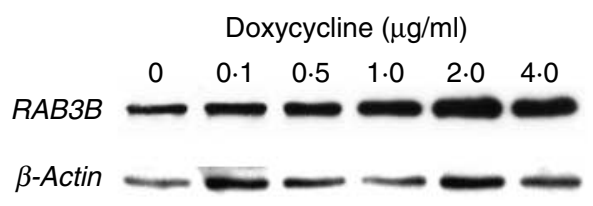

Figure 2 Inducible NGN3 expression in PANC-1 cells. (A) Northern blot analysis for NGN3 expression following the addition of doxycycline for $48 \mathrm{~h}$ to a clone of PANC- $1_{\text {iNGN3 }}$ cells. (B) Schematic of the mouse NeuroD1 promoter with two E-box motifs at $-348 /-343$ and $-241 /-236$ bp in its $5^{\prime}$ flanking region that are regulated by Ngn3-E47 dimers (Huang et al. 2000). (C) Fold induction \pm s.E.M. of luciferase activity from transient transfection of $\mathrm{p}-1613$ NeuroD1-Luc measured $48 \mathrm{~h}$ after the addition of $2 \mu \mathrm{g} / \mathrm{ml}$ doxycycline in four PANC- $1_{\text {iNGN3 }}$ clones. (D) Fold increase \pm S.E.M. of $N G N 3$ and $R A B 3 B$ expression from microarray analysis of PANC $-1_{\text {iNGN3 }}$ Clone 51 by adding $2 \mu \mathrm{g} / \mathrm{ml}$ doxycycline for $48 \mathrm{~h}$. (E and F) Western blot analysis of clone 51 PANC- $1_{\text {iNGN3 }}$ cells showing NGN3 (E) and RAB3B (F) protein expression following addition of increasing concentrations of doxycycline for $48 \mathrm{~h}$. 


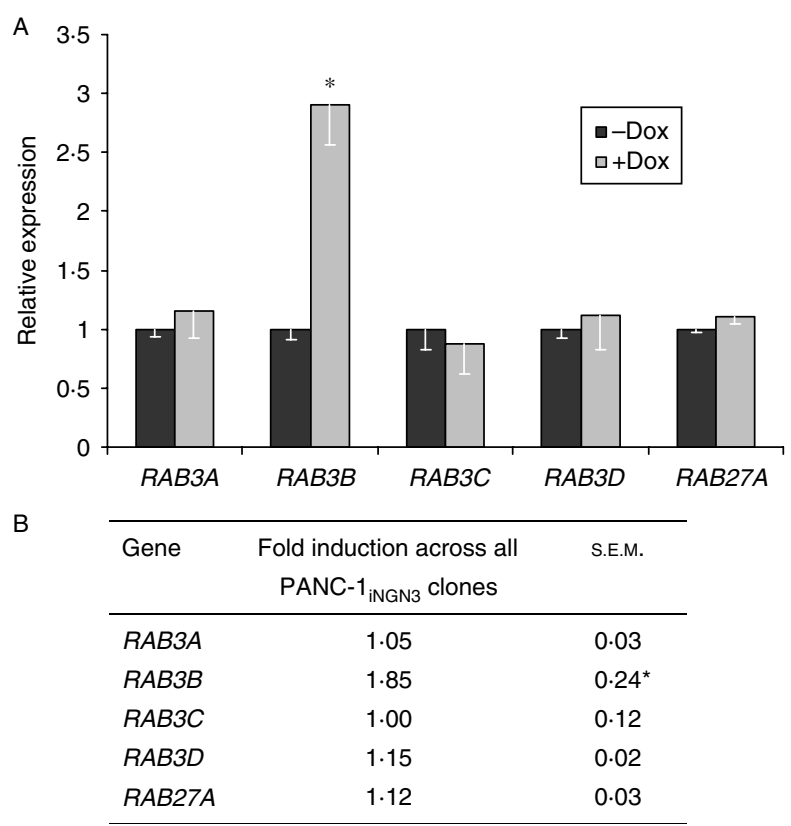

Figure 3 Expression of RAB3 family members and RAB27A following induction of NGN3 expression in PANC- $1_{\text {iNGN3 }}$ cells. (A) Expression of $R A B 3$ isoforms and $R A B 27 A$ in PANC- $1_{\text {iNGN3 }}$ clone 51 after $2 \mu \mathrm{g} / \mathrm{ml}$ doxycycline for $48 \mathrm{~h}$. Bars show mean \pm S.E.M. from at least two experiments. (B) Mean fold induction \pm S.E.M. of expression for $R A B 3$ isoforms and $R A B 27 A$ in the other PANC- $1_{\text {iNGN3 }}$ clones (Fig. $2 \mathrm{~B}$ ) after $2 \mu \mathrm{g} / \mathrm{ml}$ doxycycline for $48 \mathrm{~h}$. $* P<0.05$ compared to ' - dox' treatment.

cross-linked by exposure to ultraviolet light and hybridised at $68^{\circ} \mathrm{C}$ overnight with radiolabelled DNA probes to the NGN3 coding sequence. Following post-hybridisation washes, the membrane was exposed to autoradiography film at $-80{ }^{\circ} \mathrm{C}$ and developed.

Real-time PCR in the foetal tissue and the PANC-1 cells used pre-designed Taqman Gene Expression assays for each gene (Applied Biosystems, Warrington, UK) and an ABI PRISM 7900HT system with standard cycling conditions. TBP and HPRT1 were used as endogenous controls. Results were analysed with SDS v2.1 software (Applied Biosystems) using the relative quantification method. mRNA was isolated from human pancreatic islets using the RNeasy Mini kit (Qiagen Ltd) according to the manufacturer's instructions and was quantified using a Nanodrop spectrometer (NanoDrop, Rockland, ME, USA). cDNA was synthesised and quantitative RT-PCR standards ranging from 10 to $10^{9}$ copies DNA were prepared as described previously (Persaud et al. 2002). Real-time PCR amplification was performed using a LightCycler rapid thermal cycler system. Reactions were performed in $10 \mu \mathrm{l}$ comprising nucleotides, Taq DNA polymerase and buffer (all included in the LightCycler FastStart Reaction Mix SYBR Green I); template cDNA; $3 \mathrm{mM} \mathrm{MgCl}_{2}$; and $0.5 \mu \mathrm{M}$ primers. All PCR protocols included an initial $10 \mathrm{~min}$ denaturation step and each cycle subsequently included a ramp at $95^{\circ} \mathrm{C}$ for denaturation, annealing for $10 \mathrm{~s}$ at the temperatures listed in Supplementary Table 2, see section on supplementary data given at the end of this article and $\mathrm{a} 72{ }^{\circ} \mathrm{C}$ extension phase for $14 \mathrm{~s}(\beta$-ACTIN $)$ or $18 \mathrm{~s}$ (all other genes). The amplification products of both the primer pairs were subjected to melting point analyses and subsequent gel electrophoresis to ensure specificity of amplification.

\section{Statistical analysis}

Data were expressed as means \pm s.E.M. Statistical analysis used paired $t$-test or one-way ANOVA followed by Dunnett's post hoc test, as indicated. Values with $P<0.05$ were considered significant.

\section{Results}

Inducible NGN3 expression by PANC-1 ${ }_{i N G N 3}$ cells

In the human pancreas, cytoplasmic CK19 and nuclear SOX9 were restricted to the foetal epithelial progenitor cells and adult ductal cells (Fig. 1A and B; Piper et al. 2004). A similar profile was identified uniformly in the human pancreatic ductal carcinoma cell line, PANC-1 (Fig. 1C), which was negative for amylase (data not shown), confirming this cell line as a suitable source in which to engineer inducible NGN3 expression. Sequential stable transfection of vectors for dox-inducible NGN3 expression resulted in the isolation of more than 60 human PANC-1 ${ }_{\text {iNGN3 }}$ clones for further analysis. These starting clones retained SOX9 and CK19

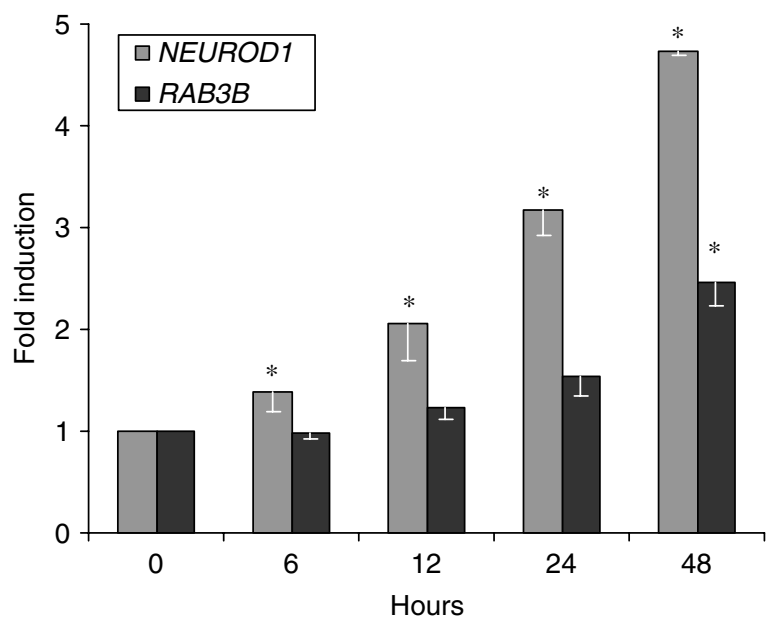

Figure 4 Timing of RAB3B expression following the induction of NGN3 in PANC $-1_{\text {iNGN3 }}$ cells. The relative expression of $R A B 3 B$ and $N E U R O D 1$ is shown following the addition of $2 \mu \mathrm{g} / \mathrm{ml}$ doxycycline to PANC- $1_{\text {iNGN3 }}$ clone 51 . Bars show mean \pm S.E.M. from two experiments. ${ }^{*} P<0.05$ following analysis by ANOVA and Dunnett's post hoc test. 
expression (data not shown). From selected clones, northern blotting revealed dose-responsive NGN3 expression (Fig. 2A). Four clones, 9, 15, 40 and 51, were analysed in greater detail. The ability of these clones to induce functional NGN3 protein after the addition of dox to the media was assessed using a luciferase construct containing two E-box motifs from the wild-type mouse NeuroD1 $5^{\prime}$ flanking region (Fig. 2B; Huang et al. 2000). All the four clones increased luciferase activity on the addition of dox to the media (Fig. 2C). Clone 51 gave the most reproducible results with least background luciferase activity and, thus, was chosen for the induction of NGN3 and subsequent microarray analysis (see Supplementary Methods, see section on supplementary data given at the end of this article). As expected, NGN3 upregulation was detected by the array (Fig. 2D). The gene encoding RAB3B was also identified from candidates whose expression was induced at least twofold by $2 \mu \mathrm{g} / \mathrm{ml}$ dox treatment for $48 \mathrm{~h}$. Reassuringly, both NGN3 and RAB3B proteins showed dose-responsive increases following dox treatment of clone 51 (Fig. 2E and F).

Expression of RAB3 family members and $R A B 27 A$ in NGN3-inducible PANC-1 cells

In the mouse central nervous system, Rab3 proteins functions redundantly due to other co-expressed family members
(Schluter et al. 2004). In mouse $\beta$-cells, inactivation of $R a b 3 a$ and $R a b 27 a$, but not Rab3b, caused glucose intolerance (Yaekura et al. 2003, Kasai et al. 2005). Therefore, we analysed whether NGN3 expression led to the expression of other $R A B 3$ genes as well as $R A B 27 A$. Following the induction of NGN3 for $48 \mathrm{~h}$, neither $R A B 3 A, R A B 3 C$ and $R A B 3 D$ family members nor $R A B 27 A$ was increased in either clone 51 (Fig. 3A) or the other PANC-1 ${ }_{\text {iNGN3 }}$ cell clones (Fig. 3B). $R A B 3 B$ was significantly increased in all the four PANC$1_{\text {iNGN3 }}$ clones, albeit to a lesser extent in clones 9,15 and 40 than in clone 51 . Spurious induction of $R A B 3 B$ by the antibiotic was excluded, as dox had no effect on $R A B 3 B$ expression in PANC-1 cells lacking the pTRE2-NGN3 vector (data not shown).

NGN3 is a transient requirement during mouse endocrine cell differentiation (Schwitzgebel et al. 2000). As exocytosis of stored hormone granules is a function of mature endocrine cells, NGN3 would not be expected to directly regulate $R A B 3 B$ expression. We examined the timing of $R A B 3 B$ expression in the PANC- $1_{\mathrm{iNGN} 3}$ cells. By northern blotting, NGN3 transcripts were induced within $2 \mathrm{~h}$ of adding dox (data not shown). mRNA levels of NEUROD1, a direct target of NGN3 action (Huang et al. 2000), were increased by $\sim 40 \%$ at $6 \mathrm{~h}$ and doubled at $12 \mathrm{~h}$. In contrast, $R A B 3 B$ transcripts accumulated relatively slowly, levels being increased only by $\sim 50 \%$ at $24 \mathrm{~h}$ after the addition of
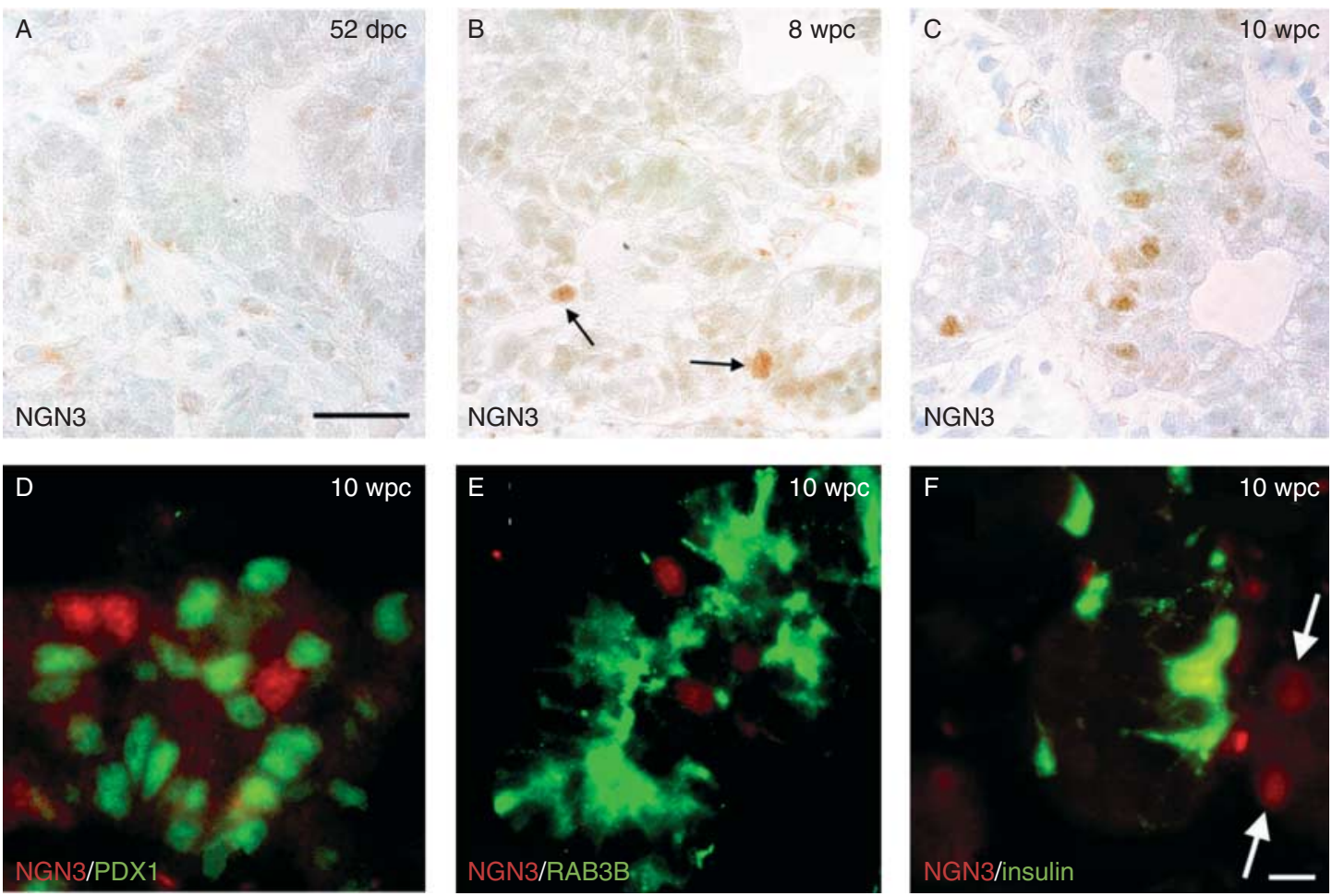

Figure 5 Expression of NGN3 during human pancreas development. (A-F) NGN3 immunohistochemistry in sections of developing human pancreas at $52 \mathrm{dpc}(\mathrm{A}), 8 \mathrm{wpc}(\mathrm{B}$, arrows point to positive cells) and $10 \mathrm{wpc}(\mathrm{C}-\mathrm{F})$. Dual immunofluorescence of NGN3 (red) and PDX1 (green) is shown in (C). (E and F) Dual immunofluorescence of NGN3 with RAB3B (E) and insulin (F). Arrows in (F) point to NGN3-positive nuclei. Size bars represent $150 \mu \mathrm{m}(\mathrm{A}-\mathrm{C})$ and $40 \mu \mathrm{m}(\mathrm{D}-\mathrm{F})$. 
Dox (Fig. 4). This implies that the effect of NGN3 on $R A B 3 B$ transcription is indirect and mediated through other transcription factors. We used RNAi to moderate the increase in NEUROD1 expression (Supplementary Figure 1, see section on supplementary data given at the end of this article). The downstream induction of $R A B 3 B$ was unaltered, indicating that it does not rely on NEUROD1 (data not shown).

\section{Expression of $\mathrm{RAB} 3 \mathrm{~B}$ during human pancreas development and in islets}

From analyses of four specimens at 50 and $52 \mathrm{dpc}$, the human embryonic pancreas was largely devoid of cells positive for NGN3 (Fig. 5A). In two specimens at $8 \mathrm{wpc}$, isolated epithelial cells with nuclei stained for NGN3 immunoreactivity were apparent centrally within the organ (arrows in Fig. 5B). At this stage, we have previously reported occasional insulin-positive cells in the same location (Piper et al. 2004). Similarly positioned NGN3-positive cells were more numerous within two specimens of larger pancreas at $10 \mathrm{wpc}$ (Fig. 5C) and they did not co-localise with PDX1 (Fig. 5D).
In keeping with an indirect induction by NGN3, neither RAB3B nor insulin-positive cells stained for NGN3 (Fig. 5E and F). RAB3B was first detected weakly by immunohistochemistry in the cytoplasm of clustered cells adjacent to the duct-like epithelial structures of the foetal pancreas at $10 \mathrm{wpc}$ (Fig. 6A and B). It was detected more robustly in the earliest foetal islets at $12 \mathrm{wpc}$ (Fig. 6C) and in the cells of adult islets (Fig. 6D). RAB3B was not found in ducts or acinar cells (Fig. 6D) of the adult pancreas. At $10 \mathrm{wpc}, \mathrm{RAB} 3 \mathrm{~B}$ co-localised with insulin and glucagon (Fig 6E-J). In the adult pancreas, RAB3B extensively co-localised with insulin but was somewhat variable in different $\beta$-cells (Fig. 7A-C). Some RAB3B was present in some $\alpha$ - and $\delta$-cell but at relatively low level (Fig. 7D-I). In contrast, RAB3B did not co-localise with pancreatic polypeptide in the adult pancreas (Fig. 7G-L). Consistent with Fig. 6D, RAB3B was not detected in CK19-positive duct cells in the adult pancreas (Fig. 7M-O). These data are consistent with the timing of $R A B 3 B$ expression following its induction by NGN3 in PANC-1 $1_{\text {iNGN3 }}$ cells (Fig. 4).

By real-time PCR, $R A B 3 B$ was detected robustly in adult islets. Its transcripts were $\sim 500$-fold increased compared to
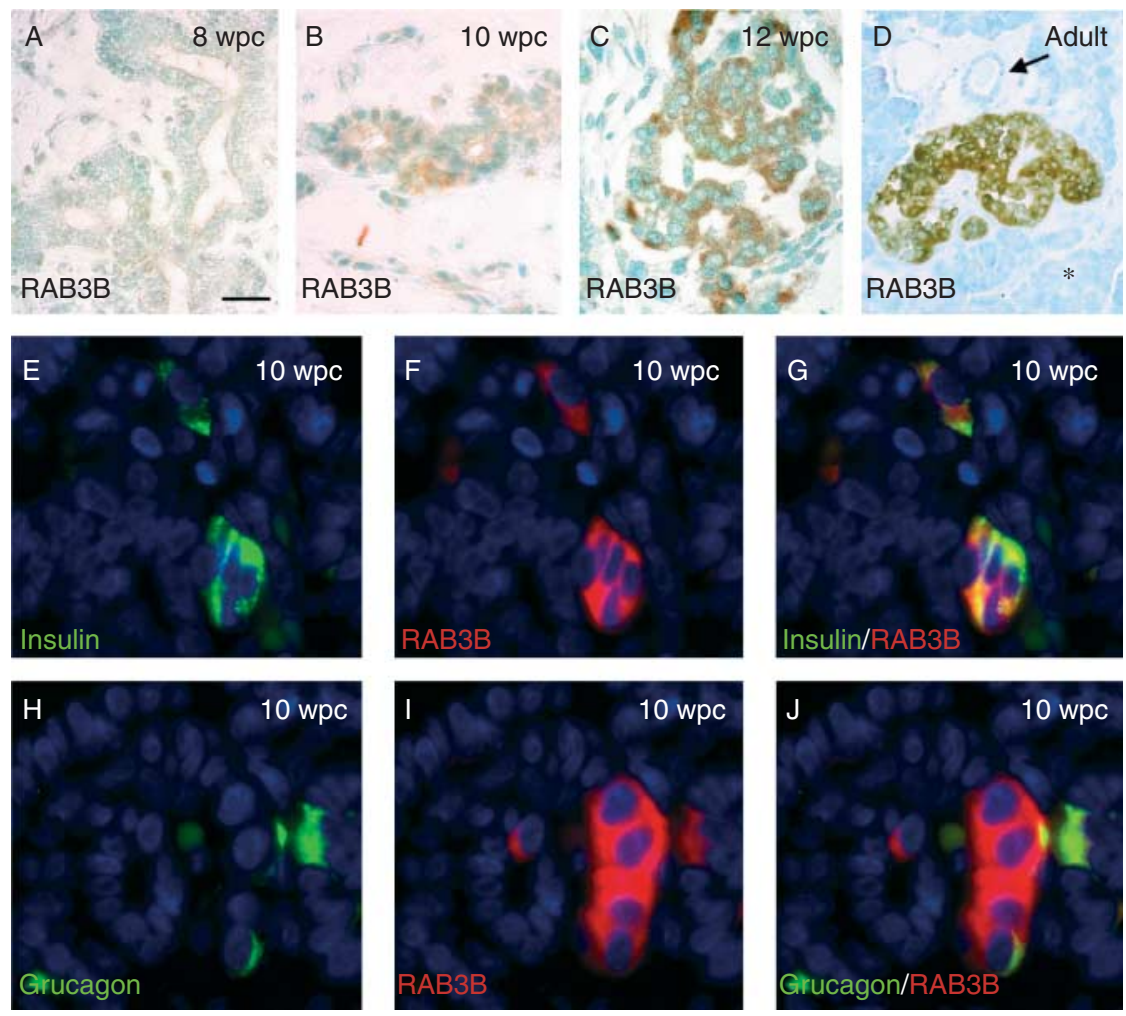

Figure 6 Expression of RAB3B during human pancreas development. (A-D) RAB3B immunohistochemistry in sections of developing human pancreas at $8 \mathrm{wpc}(\mathrm{A}), 10 \mathrm{wpc}$

(B, arrow points to faintly positive cell cluster) and $12 \mathrm{wpc}(\mathrm{C})$, and in the adult pancreas (D, arrow and star indicate duct and acinar tissue respectively). (E-J) Individual and dual immunofluorescence at 10 wpc counterstained with DAPI (blue). Size bar represents $150 \mu \mathrm{m}$ (A-C), $250 \mu \mathrm{m}(\mathrm{D})$ and $40 \mu \mathrm{m}(\mathrm{E}-\mathrm{J})$. 

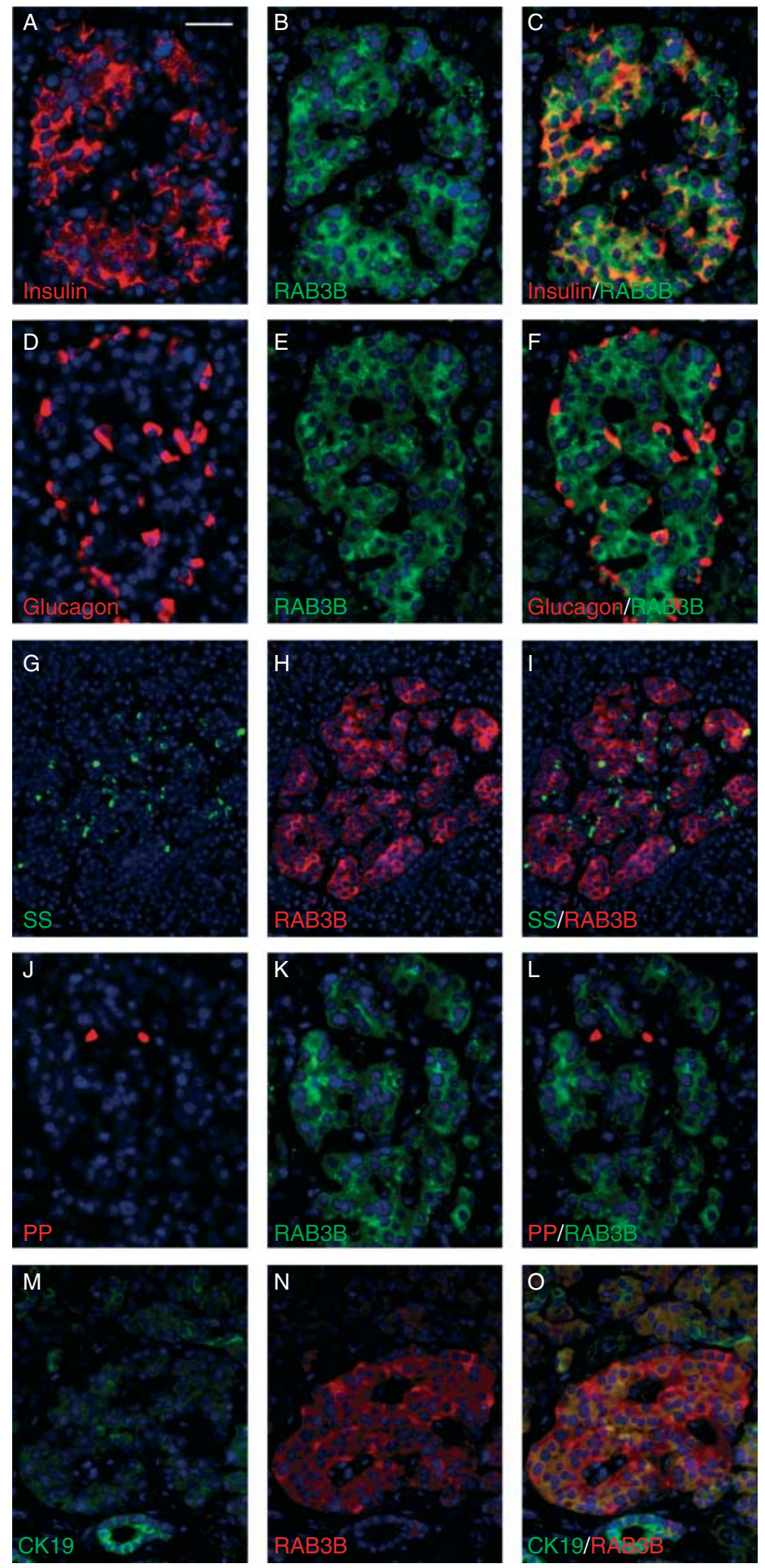

Figure 7 Expression of RAB3B in the adult pancreas. (A-O) Immunofluorescence counterstained with DAPI (blue) in sections of the adult pancreas. Size bar represents $40 \mu \mathrm{m}(\mathrm{A}-\mathrm{F}$ and $\mathrm{J}-\mathrm{O})$ and $150 \mu \mathrm{m}(\mathrm{G}-\mathrm{H})$. 


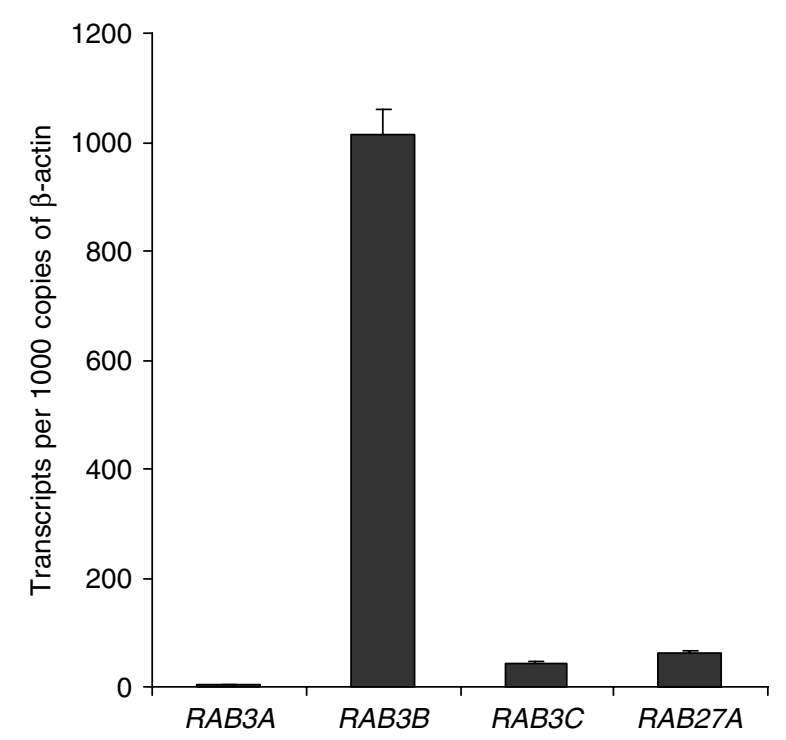

Figure 8 Expression of RAB3 family members and RAB27A in isolated human adult islets. Real-time PCR analysis of $R A B 3$ isoforms and $R A B 27 A$ in adult islets expressed relative to $\beta$-ACTIN transcript levels. RAB3D did not amplify despite the use of more than 40 cycles of PCR.

$R A B 3 A$, 25-fold increased compared to $R A B 3 C$ and 17 -fold increased compared to RAB27A (Fig. 8). RAB3D did not amplify despite 40 cycles of PCR, implying very low or absent expression compared to the other isoforms under investigation.

\section{Discussion}

Studies in mice have proven that Ngn3 is required for pancreatic endocrine cell commitment. Without the bHLH transcription factor, the islet differentiation programme fails (Gradwohl et al. 2000). Conversely, driving ectopic Ngn3 expression in all pancreatic progenitor cells leads to premature over-commitment to an endocrine cell fate (Apelqvist et al. 1999). Lineage tracing of Ngn3-positive cells marks all mature pancreatic endocrine cell types ( $\mathrm{Gu}$ et al. 2002). The transcription factor is extinguished before terminal differentiation and hormone expression (Schwitzgebel et al. 2000). Thus, it can be concluded that, in rodents, transient Ngn3 expression in an appropriate number of pancreatic epithelial progenitor cells is the normal mechanism for islet development and also appears important for potential $\beta$-cell regeneration in adult mice ( $\mathrm{Xu}$ et al. 2008). In this study, consistent with previous data describing NGN3 transcripts in the human foetal pancreas at $8 \mathrm{wpc}$ (Castaing et al. 2005), we found the transcription factor present at 8 and $10 \mathrm{wpc}$ within central cells of the pancreas where endocrine differentiation is known to predominate away from the pro-proliferative, exocrine-inducing effects of peri-pancreatic mesenchyme (Miralles et al. 1998, Polak et al. 2000, Elghazi et al. 2002,
Piper et al. 2004). At this stage of development, large numbers of insulin-positive cells are apparent before organisation into islets at the end of the first trimester (Piper et al. 2004). Coupled with the identification of hypomorphic NGN3 mutations in patients with juvenile-onset diabetes (Wang et al. 2006, Jensen et al. 2007), these findings make in vitro models useful in the search for downstream target genes of NGN3 expression in human (Heremans et al. 2002, Mellitzer et al. 2006) and in mouse cell types (Gasa et al. 2004).

Our in vitro cell line model to study the downstream consequences of NGN3 expression is an imperfect replica of human foetal pancreatic progenitors. In our experience, PANC-1 cells lack PDX1 protein. On the microarray, hybridisation signal was weak for PDX1 and unaltered by the dox treatment. However, similar in vitro models have been used by others (Gasa et al. 2004) and PDX1 was absent in the NGN3-positive foetal pancreatic cells both in this study and in mouse (Schwitzgebel et al. 2000). Our cloned cells did uniformly express SOX9 and CK19 mimicking foetal pancreatic progenitor cells and an adult ductal phenotype. Nevertheless, by the ectopic expression of a single gene in a tumour cell line, it is inconceivable to generate bona fide $\beta$-cell precursors with complete, faithful gene expression profiles. Hence, our model of inducible NGN3 expression was used as a tool to identify downstream candidate markers of human $\beta$-cells for validation in the native cell type. NGN3 expression promptly activated NEUROD1, which encodes a transcription factor that has been linked causally with various forms of non-autoimmune diabetes (Frayling et al. 2001). Our model also allowed detection of RAB3B, which was subsequently shown to localise robustly to the human foetal and adult $\beta$-cells.

There are four RAB3 family members. Regazzi et al. (1996) previously showed RAB3B and RAB3C, but not RAB3A, by immunoblotting of whole human islets, comprising multiple hormone-secreting cell types. At that time, RAB3D was not assessed. In rat and mouse, Rab3a and Rab27a are very important regulators of exocytosis, both in vitro and in vivo, in $\beta$-cells (Regazzi et al. 1996, Yi et al. 2002, Waselle et al. 2003, Yaekura et al. 2003, Kasai et al. 2005, Abderrahmani et al. 2006). Through the interaction with a network of interacting proteins, they coordinate the intracellular trafficking of insulin granules that culminate in docking at the cell membrane and insulin release (Yi et al. 2002, Waselle et al. 2003). Rab3a and Rab27a knockout mice show defects in glucose-stimulated insulin secretion (GSIS) similar to those observed in patients with type 2 diabetes and in mice lacking the glucagon-like peptide-1 (GLP-1) receptor (Scrocchi et al. 1996, Yaekura et al. 2003, Aizawa \& Komatsu 2005, Kasai et al. 2005). Furthermore, hyperglycaemia drastically reduced levels of Rab3a and Rab27a protein in rat $\beta$-cells as a consequence of expression of the transcriptional repressor, inducible cAMP early repressor (Abderrahmani et al. 2006). It transpires that GLP-1 potentiation of insulin secretion requires a complex between the cAMP sensor protein cAMP-GEFII, bound to the 
sulphonylurea receptor 1, a protein called Piccolo and Rab-interacting molecule 2 (RIM2; Ozaki et al. 2000, Kashima et al. 2001, Fujimoto et al. 2002, Shibasaki et al. 2004). RIM2 then interacts with the RAB protein at the insulin granule, thus linking GLP-1 signalling and events at the ATP-sensitive potassium channel to insulin secretion. This emerging understanding of an important mechanism underlying GSIS makes the identification of the prevalent $\mathrm{RAB}$ isoform(s) in human $\beta$-cells important.

In this study, RAB3B was the only family member induced as a consequence of NGN3 expression. Its induction by NGN3 occurred later than that of NEUROD1, which, along with the non-overlapping expression profiles in developmental material, implies indirect regulation of $R A B 3 B$ by NGN3. We show that RAB3B was extensively localised to $\beta$-cells both during human foetal development and in adult islets with some expression in some adult $\alpha$ - and $\delta$-cells. Analysis of human adult islets demonstrated $R A B 3 B$ expression to be approximately equal to the transcript numbers of $\beta$-ACTIN, present in all islet cell types, and greatly in excess of those for $R A B 3 A, R A B 3 C, R A B 3 D$ and $R A B 27 A$. The level of $R A B 3 B$ transcripts detected equates to $\sim 20-50 \%$ of those which we have previously found for insulin (data not shown). In the mouse central nervous system, Rab3 family members regulate the exocytosis of neurotransmitters in a redundant manner, all isoforms needing inactivation to generate an epileptic phenotype (Schluter et al. 2004). This raises the question of whether redundant function could also affect pancreatic $\beta$-cell function. Although feasible, this seems unlikely: $R A B 3 A$ and $R A B 3 C$ transcripts were only weakly detected and $R A B 3 D$ was not detected in islets whereas in the central nervous system, under normal conditions, all Rab3 isoforms are expressed (Schluter et al. 2004); in in vitro analysis of rat melanotrophs, Rab3b could not substitute for the function of Rab3a (Rupnik et al. 2007); inactivation of either Rab3a or $R a b 27 a$ in isolation produced glucose intolerance in mice (implying non-redundant function; Yaekura et al. 2003, Kasai et al. 2005); over-expression of Rab3a and Rab27a protein in MIN6 cells generated different effects on insulin secretion (Yi et al. 2002); and in dopaminergic nerves, over-expressing RAB3B, but not RAB3A, was protective in the models of Parkinson's disease (Chung et al. 2009). Interestingly, on searching the Unigene database, Rab3b is absent from cDNA libraries generated from mouse or rat insulinoma cell lines. Twelve of the 13 pancreatic clones for human $R A B 3 B$ arise from the islet or insulinoma sources. Conversely, $R A B 3 A$, inactivation of which causes glucose intolerance in mice (Yaekura et al. 2003), has not been identified from Unigene human islet or insulinoma cDNA libraries.

There is a clear involvement of mutations in the pathway between the ATP-sensitive potassium channel and insulin secretion as causes of permanent neonatal diabetes (Gloyn et al. 2004). RAB3B localises to $1 \mathrm{p} 31-\mathrm{p} 32$, a locus previously linked to glucose intolerance and diabetes (Hsueh et al. 2003). We have conducted preliminary screens in three cases of permanent neonatal diabetes with linkage to this locus without identifying causative mutations in the $R A B 3 B$ coding region. Irrespective of this, the potential for agents targeted at RAB function as novel potentiators of GSIS has already been proposed (Aizawa \& Komatsu 2005). It will be important to ensure such efforts target the appropriate protein. In this study, we identified $R A B 3 B$ as an indirect target of NGN3 expression. Under normal circumstances, $R A B 3 B$ is clearly the predominant family member in human islets representing a significant difference in gene expression across species. Specifically, neither RAB3A nor RAB27A appears as likely to play the important role in human $\beta$-cells that has been described for the equivalent rodent cells (Regazzi et al. 1996, Yi et al. 2002, Waselle et al. 2003, Kasai et al. 2005, Abderrahmani et al. 2006).

\section{Supplementary data}

This is linked to the online version of the paper at http://dx.doi.org/10.1677/ JOE-10-0120.

\section{Declaration of interest}

The authors declare that there is no conflict of interest that could be perceived as prejudicing the impartiality of the research reported.

\section{Funding}

This work was funded by an innovation grant from the Juvenile Diabetes Research Foundation (JDRF). NH is a Wellcome Trust Senior Fellow in Clinical Science and received support from the Wellcome Trust (in partnership with JDRF). $\mathrm{NH}$ and $\mathrm{KPH}$ received support from the Manchester NIHR Biomedical Research Centre.

\section{Acknowledgements}

The authors are grateful to Anne Chad and colleagues at the Quays Clinic and the Princess Anne Hospital for the collection of human foetal material and to Dr Guo-Cai Huang, Dr Shanta Persaud and Prof. Stephanie Amiel and Prof. Peter Jones (all King's College Hospital, London, UK) for supplying the human islets used in this study.

\section{References}

Abderrahmani A, Cheviet S, Ferdaoussi M, Coppola T, Waeber G \& Regazzi R 2006 ICER induced by hyperglycemia represses the expression of genes essential for insulin exocytosis. EMBO Journal 25 977-986. (doi:10.1038/sj.emboj.7601008)

Aizawa T \& Komatsu M 2005 Rab27a: a new face in beta cell metabolismsecretion coupling. Journal of Clinical Investigation 115 227-230. (doi:10. 1172/JCI24269)

Apelqvist A, Li H, Sommer L, Beatus P, Anderson DJ, Honjo T, Hrabe de Angelis M, Lendahl U \& Edlund H 1999 Notch signalling controls pancreatic cell differentiation. Nature 400 877-881. (doi:10.1038/23716)

Babu DA, Chakrabarti SK, Garmey JC \& Mirmira RG 2008 Pdx1 and BETA2/NeuroD1 participate in a transcriptional complex that mediates short-range DNA looping at the insulin gene. Journal of Biological Chemistry 283 8164-8172. (doi:10.1074/jbc.M800336200) 
Brun T, He KH, Lupi R, Boehm B, Wojtusciszyn A, Sauter N, Donath M, Marchetti P, Maedler K \& Gauthier BR 2008 The diabetes-linked transcription factor Pax4 is expressed in human pancreatic islets and is activated by mitogens and GLP-1. Human Molecular Genetics 17 478-489. (doi:10.1093/hmg/ddm325)

Castaing M, Duvillie B, Quemeneur E, Basmaciogullari A \& Scharfmann R 2005 Ex vivo analysis of acinar and endocrine cell development in the human embryonic pancreas. Developmental Dynamics 234 339-345. (doi:10. 1002/dvdy.20547)

Chung CY, Koprich JB, Hallett PJ \& Isacson O 2009 Functional enhancement and protection of dopaminergic terminals by RAB3B overexpression. PNAS 106 22474-22479. (doi:10.1073/pnas.0912193106)

Elghazi L, Cras-Meneur C, Czernichow P \& Scharfmann R 2002 Role for FGFR2IIIb-mediated signals in controlling pancreatic endocrine progenitor cell proliferation. PNAS 99 3884-3889. (doi:10.1073/pnas.062321799)

Frayling TM, Evans JC, Bulman MP, Pearson E, Allen L, Owen K, Bingham C, Hannemann M, Shepherd M, Ellard S et al. $2001 \beta$-Cell genes and diabetes: molecular and clinical characterization of mutations in transcription factors. Diabetes 50 (Suppl 1) S94-S100. (doi:10.2337/diabetes.50. 2007.S94)

Fujimoto K, Shibasaki T, Yokoi N, Kashima Y, Matsumoto M, Sasaki T, Tajima N, Iwanaga T \& Seino S 2002 Piccolo, a $\mathrm{Ca}^{2+}$ sensor in pancreatic beta-cells. Involvement of cAMP-GEFII.Rim2.Piccolo complex in cAMP-dependent exocytosis. Journal of Biological Chemistry 277 50497-50502. (doi:10.1074/jbc.M210146200)

Gasa R, Mrejen C, Leachman N, Otten M, Barnes M, Wang J, Chakrabarti S, Mirmira R \& German M 2004 Proendocrine genes coordinate the pancreatic islet differentiation program in vitro. PNAS 101 13245-13250. (doi:10.1073/pnas.0405301101)

Gloyn AL, Pearson ER, Antcliff JF, Proks P, Bruining GJ, Slingerland AS, Howard N, Srinivasan S, Silva JM, Molnes J et al. 2004 Activating mutations in the gene encoding the ATP-sensitive potassium-channel subunit Kir6.2 and permanent neonatal diabetes. New England Journal of Medicine 350 1838-1849. (doi:10.1056/NEJMoa032922)

Gonzalez L Jr \& Scheller RH 1999 Regulation of membrane trafficking: structural insights from a Rab/effector complex. Cell 96 755-758. (doi:10.1016/S0092-8674(00)80585-1)

Gradwohl G, Dierich A, LeMeur M \& Guillemot F 2000 Neurogenin3 is required for the development of the four endocrine cell lineages of the pancreas. PNAS 97 1607-1611. (doi:10.1073/pnas.97.4.1607)

Gu G, Dubauskaite J \& Melton DA 2002 Direct evidence for the pancreatic lineage: NGN3 + cells are islet progenitors and are distinct from duct progenitors. Development 129 2447-2457.

Hanley NA, Rainey WE, Wilson DI, Ball SG \& Parker KL 2001 Expression profiles of SF-1, DAX1, and CYP17 in the human fetal adrenal gland: potential interactions in gene regulation. Molecular Endocrinology 15 57-68. (doi:10.1210/me.15.1.57)

Hay CW \& Docherty K 2006 Comparative analysis of insulin gene promoters: implications for diabetes research. Diabetes 55 3201-3213. (doi:10.2337/ db06-0788)

Heremans Y, Van De Casteele M, in't Veld P, Gradwohl G, Serup P, Madsen O, Pipeleers D \& Heimberg H 2002 Recapitulation of embryonic neuroendocrine differentiation in adult human pancreatic duct cells expressing neurogenin 3. Journal of Cell Biology 159 303-312. (doi:10.1083/ jcb.200203074)

Hsueh WC, St Jean PL, Mitchell BD, Pollin TI, Knowler WC, Ehm MG, Bell CJ, Sakul H, Wagner MJ, Burns DK et al. 2003 Genome-wide and fine-mapping linkage studies of type 2 diabetes and glucose traits in the Old Order Amish: evidence for a new diabetes locus on chromosome 14q11 and confirmation of a locus on chromosome 1q21-q24. Diabetes 52 550-557. (doi:10.2337/diabetes.52.2.550)

Huang HP, Liu M, El-Hodiri HM, Chu K, Jamrich M \& Tsai MJ 2000 Regulation of the pancreatic islet-specific gene BETA2 (neuroD) by neurogenin 3. Molecular and Cellular Biology 20 3292-3307. (doi:10.1128/ MCB.20.9.3292-3307.2000)

Huang GC, Zhao M, Jones P, Persaud S, Ramracheya R, Lobner K, Christie MR, Banga JP, Peakman M, Sirinivsan P et al. 2004 The development of new density gradient media for purifying human islets and islet-quality assessments. Transplantation 77 143-145. (doi:10.1097/01.TP.0000100401. 62912.B2)

Jensen JN, Rosenberg LC, Hecksher-Sorensen J \& Serup P 2007 Mutant neurogenin-3 in congenital malabsorptive diarrhea. New England Journal of Medicine 356 1781-1782. (doi:10.1056/NEJMc063247)

Johnson D, Shepherd RM, Gill D, Gorman T, Smith DM \& Dunne MJ 2007 Glucokinase activators: molecular tools for studying the physiology of insulin-secreting cells. Biochemical Society Transactions 35 1208-1210. (doi:10.1042/BST0351208)

Kasai K, Ohara-Imaizumi M, Takahashi N, Mizutani S, Zhao S, Kikuta T, Kasai H, Nagamatsu S, Gomi H \& Izumi T 2005 Rab27a mediates the tight docking of insulin granules onto the plasma membrane during glucose stimulation. Journal of Clinical Investigation 115 388-396. (doi:10.1172/ JCI22955)

Kashima Y, Miki T, Shibasaki T, Ozaki N, Miyazaki M, Yano H \& Seino S 2001 Critical role of cAMP-GEFII-Rim2 complex in incretin-potentiated insulin secretion. Journal of Biological Chemistry 276 46046-46053. (doi:10. 1074/jbc.M108378200)

Lynn FC, Smith SB, Wilson ME, Yang KY, Nekrep N \& German MS 2007 Sox 9 coordinates a transcriptional network in pancreatic progenitor cells. PNAS 104 10500-10505. (doi:10.1073/pnas.0704054104)

McDonald TJ, Tu E, Brenner S, Zabel P, Behme M, Panchal C, Hramiak I, Barnett WB, Miller D \& Dupre J 1994 Canine, human, and rat plasma insulin responses to galanin administration: species response differences. American Journal of Physiology 266 E612-E617.

McKinnon CM \& Docherty K 2001 Pancreatic duodenal homeobox-1, PDX-1, a major regulator of beta cell identity and function. Diabetologia 44 1203-1214. (doi:10.1007/s001250100628)

Mellitzer G, Bonne S, Luco RF, Van De Casteele M, Lenne-Samuel N, Collombat P, Mansouri A, Lee J, Lan M, Pipeleers D et al. 2006 IA1 is NGN3-dependent and essential for differentiation of the endocrine pancreas. EMBO Journal 25 1344-1352. (doi:10.1038/sj.emboj. 7601011)

Miralles F, Czernichow P \& Scharfmann R 1998 Follistatin regulates the relative proportions of endocrine versus exocrine tissue during pancreatic development. Development 125 1017-1024.

Murtaugh LC 2007 Pancreas and beta-cell development: from the actual to the possible. Development 134 427-438. (doi:10.1242/dev.02770)

Ostrer H, Wilson DI \& Hanley NA 2006 Human embryo and early fetus research. Clinical Genetics 70 98-107. (doi:10.1111/j.1399-0004.2006. 00640.x)

Ozaki N, Shibasaki T, Kashima Y, Miki T, Takahashi K, Ueno H, Sunaga Y, Yano H, Matsuura Y, Iwanaga T et al. 2000 cAMP-GEFII is a direct target of cAMP in regulated exocytosis. Nature Cell Biology 2 805-811. (doi:10. 1038/35041046)

Persaud SJ, Roderigo-Milne HM, Squires PE, Sugden D, Wheeler-Jones CP, Marsh PJ, Belin VD, Luther MJ \& Jones PM 2002 A key role for beta-cell cytosolic phospholipase A(2) in the maintenance of insulin stores but not in the initiation of insulin secretion. Diabetes 51 98-104. (doi:10.2337/ diabetes.51.1.98)

Piper K, Ball SG, Keeling JW, Mansoor S, Wilson DI \& Hanley NA 2002 Novel SOX9 expression during human pancreas development correlates to abnormalities in Campomelic dysplasia. Mechanisms of Development 116 223-226. (doi:10.1016/S0925-4773(02)00145-4)

Piper K, Brickwood S, Turnpenny LW, Cameron IT, Ball SG, Wilson DI \& Hanley NA 2004 Beta cell differentiation during early human pancreas development. Journal of Endocrinology 181 11-23. (doi:10.1677/joe.0. 1810011)

Piper Hanley K, Oakley F, Sugden S, Wilson DI, Mann DA \& Hanley NA 2008 Ectopic SOX9 mediates extracellular matrix deposition characteristic of organ fibrosis. Journal of Biological Chemistry 283 14063-14071. (doi:10. 1074/jbc.M707390200)

Polak M, Bouchareb-Banaei L, Scharfmann R \& Czernichow P 2000 Early pattern of differentiation in the human pancreas. Diabetes 49 225-232. (doi:10.2337/diabetes.49.2.225) 
Potikha T, Kassem S, Haber EP, Ariel I \& Glaser B 2005 p57Kip2 (cdkn1c): sequence, splice variants and unique temporal and spatial expression pattern in the rat pancreas. Laboratory Investigation 85 364-375. (doi:10.1038/ labinvest.3700229)

Ramracheya RD, Muller DS, Squires PE, Brereton H, Sugden D, Huang GC, Amiel SA, Jones PM \& Persaud SJ 2008 Function and expression of melatonin receptors on human pancreatic islets. Journal of Pineal Research 44 273-279. (doi:10.1111/j.1600-079X.2007.00523.x)

Regazzi R, Ravazzola M, Iezzi M, Lang J, Zahraoui A, Andereggen E, Morel P, Takai Y \& Wollheim CB 1996 Expression, localization and functional role of small GTPases of the Rab3 family in insulin-secreting cells. Journal of Cell Science 109 2265-2273.

Richardson CC, Hussain K, Jones PM, Persaud S, Lobner K, Boehm A, Clark A \& Christie MR 2007 Low levels of glucose transporters and K + ATP channels in human pancreatic beta cells early in development. Diabetologia 50 1000-1005. (doi:10.1007/s00125-007-0644-x)

Rupnik M, Kreft M, Nothias F, Grilc S, Bobanovic LK, Johannes L, Kiauta T, Vernier P, Darchen F \& Zorec R 2007 Distinct role of Rab3A and Rab3B in secretory activity of rat melanotrophs. American Journal of Physiology. Cell Physiology 292 C98-C105. (doi:10.1152/ajpcell.00005.2006)

Schluter OM, Schmitz F, Jahn R, Rosenmund C \& Sudhof TC 2004 A complete genetic analysis of neuronal Rab3 function. Journal of Neuroscience 24 6629-6637. (doi:10.1523/JNEUROSCI.1610-04.2004)

Schuit FC 1997 Is GLUT2 required for glucose sensing? Diabetologia 40 104-111. (doi:10.1007/s001250050651)

Schwitzgebel VM, Scheel DW, Conners JR, Kalamaras J, Lee JE, Anderson DJ, Sussel L, Johnson JD \& German MS 2000 Expression of neurogenin3 reveals an islet cell precursor population in the pancreas. Development $\mathbf{1 2 7}$ 3533-3542.

Scrocchi LA, Brown TJ, MaClusky N, Brubaker PL, Auerbach AB, Joyner AL \& Drucker DJ 1996 Glucose intolerance but normal satiety in mice with a null mutation in the glucagon-like peptide 1 receptor gene. Nature Medicine 2 1254-1258. (doi:10.1038/nm1196-1254)

Seymour PA, Freude KK, Tran MN, Mayes EE, Jensen J, Kist R, Scherer G \& Sander M 2007 SOX9 is required for maintenance of the pancreatic progenitor cell pool. PNAS 104 1865-1870. (doi:10.1073/pnas. 0609217104)

Shibasaki T, Sunaga Y, Fujimoto K, Kashima Y \& Seino S 2004 Interaction of ATP sensor, cAMP sensor, $\mathrm{Ca}^{2+}$ sensor, and voltage-dependent $\mathrm{Ca}^{2+}$ channel in insulin granule exocytosis. Journal of Biological Chemistry 279 7956-7961. (doi:10.1074/jbc.M309068200)

Smith SB, Watada H \& German MS 2004 Neurogenin3 activates the islet differentiation program while repressing its own expression. Molecular Endocrinology 18 142-149. (doi:10.1210/me.2003-0037)
Sosa-Pineda B, Chowdhury K, Torres M, Oliver G \& Gruss P 1997 The Pax4 gene is essential for differentiation of insulin-producing beta cells in the mammalian pancreas. Nature 386 399-402. (doi:10.1038/ 386399a0)

Sussel L, Kalamaras J, Hartigan-O'Connor DJ, Meneses JJ, Pedersen RA, Rubenstein JL \& German MS 1998 Mice lacking the homeodomain transcription factor Nkx2.2 have diabetes due to arrested differentiation of pancreatic beta cells. Development 125 2213-2221.

Wang J, Cortina G, Wu SV, Tran R, Cho JH, Tsai MJ, Bailey TJ, Jamrich M, Ament ME, Treem WR et al. 2006 Mutant neurogenin-3 in congenital malabsorptive diarrhea. New England Journal of Medicine 355 270-280. (doi:10.1056/NEJMoa054288)

Waselle L, Coppola T, Fukuda M, Iezzi M, El-Amraoui A, Petit C \& Regazzi R 2003 Involvement of the Rab27 binding protein Slac2c/ MyRIP in insulin exocytosis. Molecular Biology of the Cell 14 4103-4113. (doi:10.1091/mbc.E03-01-0022)

Wilson ME, Scheel D \& German MS 2003 Gene expression cascades in pancreatic development. Mechanisms of Development 120 65-80. (doi:10. 1016/S0925-4773(02)00333-7)

Xu X, D'Hoker J, Stange G, Bonne S, De Leu N, Xiao X, Van de Casteele M, Mellitzer G, Ling Z, Pipeleers D et al. 2008 Beta cells can be generated from endogenous progenitors in injured adult mouse pancreas. Cell 132 197-207. (doi:10.1016/j.cell.2007.12.015)

Yaekura K, Julyan R, Wicksteed BL, Hays LB, Alarcon C, Sommers S, Poitout V, Baskin DG, Wang Y, Philipson LH et al. 2003 Insulin secretory deficiency and glucose intolerance in Rab3A null mice. Journal of Biological Chemistry 278 9715-9721. (doi:10.1074/jbc. M211352200)

Yi Z, Yokota H, Torii S, Aoki T, Hosaka M, Zhao S, Takata K, Takeuchi T \& Izumi T 2002 The Rab27a/granuphilin complex regulates the exocytosis of insulin-containing dense-core granules. Molecular and Cellular Biology 22 1858-1867. (doi:10.1128/MCB.22.6. 1858-1867.2002)

Zawalich WS, Bonnet-Eymard M \& Zawalich KC 1998 Glucose-induced desensitization of the pancreatic beta-cell is species dependent. American Journal of Physiology 275 E917-E924.

Received in final form 5 August 2010
Accepted 31 August 2010
Made available online as an Accepted Preprint
31 August 2010

